\title{
Investigation of Crisis Management Structure of the Selected Countries with an Emphasis on Natural Disasters Using Multi-Case Study Method
}

\author{
Ali Asghar Melk Afzali ${ }^{1} \&$ Daryush Shojaei ${ }^{1}$ \\ ${ }^{1}$ Faculty of Arts and Architecture, Islamic Azad University, South Tehran Branch, Iran \\ Correspondence: Daryush Shojaei, Faculty of Arts and Architecture, Islamic Azad University, South Tehran \\ Branch, Iran. E-mail: daruoshshoojaei@gmail.com
}

Received: June 11, 2016 Accepted: June 28, 2016 Online Published: October 30, 2016

doi:10.5539/jpl.v9n9p162 URL: http://dx.doi.org/10.5539/jpl.v9n9p162

\begin{abstract}
Since Iran is regarded as a high risky country in terms of natural disasters, it is essential to pay attention to the crisis management agendas. One of the approaches used for disaster management is a community-based approach. This paper aims to take a positive step in direction of optimal disaster management, by studying and investigating the disaster management structures of both developed and developing countries in terms of climate and occurrence of disaster similarities between target countries (U.S.A, Canada, Japan, turkey, India, Pakistan) and Islamic republic of Iran, by adopting the comparative study method. The findings indicate that there is an authenticity between type and extent of development and decentralized structure of the disaster management; as a result the decentralized structure provides a required arena for comprehensive participation at various levels. The social capability subjected to the dangers will be increased in confronting disasters and society recover to the prior state will be boosted, if authorities can establish a balance between provincial, city, district and rural capacities and potentials usage of Iran and planning in all cycles of disaster management and decentralized structure.
\end{abstract}

Keywords: crisis management, multi-case study research, natural disaster, society recovery

\section{Introduction}

Mortality, physical and psychological injuries, outbreaks of infectious diseases, famine, reduction of food, population transportation etc. all are among the impacts and consequences of natural disasters. Cities and countries are always menaced by occurrence of earthquakes, food along with man-made disasters, technological and political threats (Tehran Urban Planning and Research Center (TUPRC, 2004). With regard to the estimations of natural disasters, it can be claimed that about 30 percent of the deaths is related to the developed countries, while 70 percent of the moralities is related to the developing countries. These findings imply the deterioration of the conditions and significance of the topic for developing countries (Academy of Medical Sciences, 2009). Throughout the human history, the life and estates of human have always been exposed to the dangers of unexpected events and deadly horrific disasters, so the dangers and damages of such events, including earthquake, storm and misery wars are always recorded and identified. According to the global experience, the individual and social security and sustainable development goad will be also subjected to a serious dangers and problems, if the emergency conditions and, disasters dangers, damages and consequences are not being managed in a logical and effective manner. The historical background of Iran demonstrates that the topic of disaster management has been took into account following occurrence of different events, during various periods, but a structure coherence approach has been never devised for confronting with disasters. So that, we have always faced with various inconsistencies and defects during management of natural disasters, which implies that disaster management system is suffering from severe imperfections (Headquarter secretariat and crisis prevention and management during natural disasters and unexpected events). For human being, it is more desirable not to encounter with any disaster, so he can continue his normal life route without facing with any kind of danger. As a result, the majority of human's attempts are focused on presenting solutions for disasters and crisis prevention. Crisis management is defined a series of operations, act and lined dynamic measures, and it is based on classical management functions, including planning, organizing, leading and controlling (Asadi, 1991). 


\section{Materials \& Methods}

Method: multi-case study research

Search System: post-positivist

Research Strategy: Multi-case study researches

Although during the past 40 years, the occurrence of events including, earthquake, volcano, storm, flood, landslides, etc. in an international arena has been increased, but the valid statics and reports indicate the considerable reduction of morality percentage which is realized mainly due to the preparedness, trainings and adoption of an accurate crisis management. Written planes and their normative execution in developed countries have led to increase in resistance of cities and structures, as a results human causalities and economic dangers have been minimized. With regard to the estimations 30 percent and 70 percent of causalities originating from occurrence of huge disasters, were related to the developed and developing countries, respectively. These findings refer to the deterioration degree of the conditions and significance of the topic in developing countries (Academy of Medical Sciences, 2009).

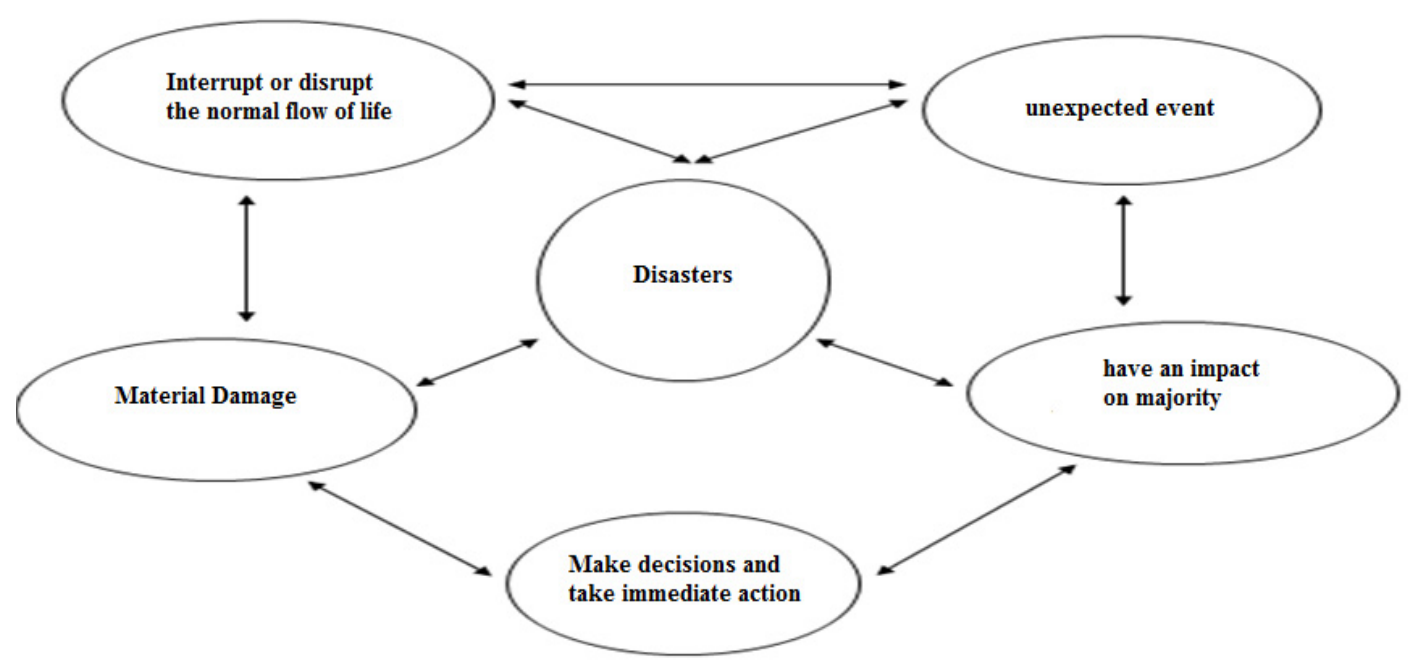

Figure 1. Graphical representation of disaster concept (Tabarsa, 2002, pp: 9-14)

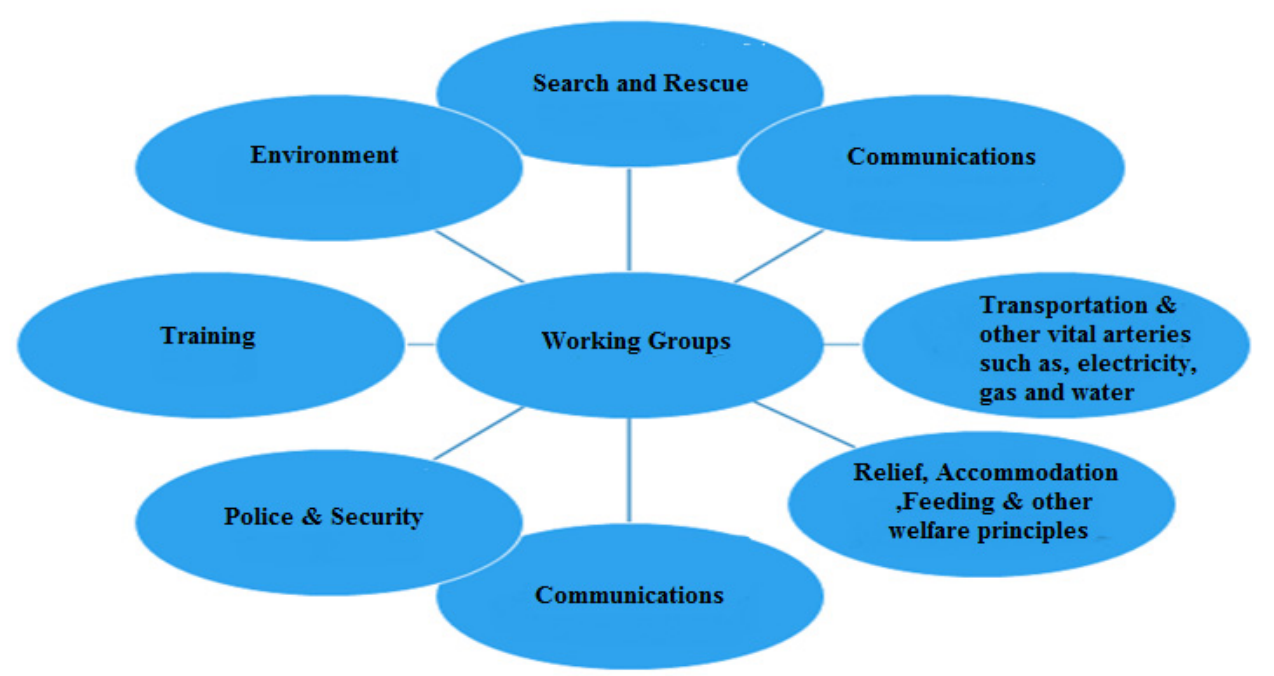

Figure 2. Groups concerned with disaster management (Alamdari, 2005, pp: 22-23) 


\section{Research Hypothesis}

Seemingly, there is a direct significant relation between decentralized structure and optimal disasters management. Hence, it is important to conduct a research focusing on this relation, with regard to the specific government structure of Iran. Moreover, three main principles, including accuracy, speed and precision should be considered in all phases of disasters management. The main objective of this study is to scrutinize concordance between developed, developing counties and Iran.

\section{Research Questions}

a) What are details of disaster management structure in countries with disaster management system and is there a direct relation between optimal disaster management and decentralized structure?

b) Is there a concordance between developed countries (U.S.A, Canada, Japan), developing countries (Turkey, India, Pakistan) and Iran, in terms of disasters management structure?

\section{Research Objectives}

\subsection{Ideal Goal}

The ideal goal of the recent research can be considered as identifying the best and most suitable structure of crisis management for mitigation of damages.

\subsection{General Goal}

The general goal refers to Investigating the structure of crisis management regarding the selected counties with an emphasis on natural disasters.

\subsection{Specific Objectives}

1) Identifying the disaster management structure of the countries with disaster management system.

2) Concordance between selected countries and Iran, in terms of disasters management.

Table1. Government structure and development level of the countries under study

\begin{tabular}{|c|c|c|c|c|c|c|c|}
\hline \multirow[t]{2}{*}{ Country } & \multicolumn{3}{|c|}{ Governing Structure } & \multirow{2}{*}{ Government Type } & \multirow{2}{*}{$\begin{array}{l}\text { Development } \\
\text { Category }\end{array}$} & \multirow{2}{*}{$\begin{array}{l}\text { Country's } \\
\text { Power }\end{array}$} & \multirow{2}{*}{ Considerations } \\
\hline & Centralized & semi-centralized & Decentralized & & & & \\
\hline Canada & & & $x$ & Governor-general & Developed & Governor-general & Prime Minister \\
\hline Japan & & & $x$ & Empire & Developed & Empire & Prime Minister \\
\hline India & & $x$ & & $\begin{array}{l}\text { Multiparty Federal } \\
\text { Republic }\end{array}$ & Developing & President & Prime Minister \\
\hline U.S.A & & & $x$ & Federal Republic & Developed & President & Prime Minister \\
\hline Turkey & $x$ & & & Multiparty republic & Developing & President & Prime Minister \\
\hline Pakistan & & $x$ & & Islamic Republic & Developing & President & Prime Minister \\
\hline Iran & $x$ & & & Islamic Republic & Developing & Revolution Leader & $\begin{array}{l}\text { President without } \\
\text { prime minister }\end{array}$ \\
\hline
\end{tabular}

Table2. Comparison between under study countries in terms of common natural disasters

\begin{tabular}{|c|c|c|c|c|c|c|c|c|c|c|c|c|c|}
\hline Country & Earthquake & $\begin{array}{c}\text { Ice } \\
\text { Storm }\end{array}$ & $\begin{array}{l}\text { Heavy } \\
\text { Snow }\end{array}$ & $\begin{array}{c}\text { Heavy } \\
\text { Rain }\end{array}$ & Drought & Flood & $\begin{array}{c}\text { Strong } \\
\text { storm }\end{array}$ & Tsunami & Volcano & Hurricanee & Tornado & $\begin{array}{c}\text { forest } \\
\text { fire }\end{array}$ & Landslides \\
\hline Canada & - & + & + & + & - & + & - & - & - & - & - & - & - \\
\hline India & + & - & - & + & + & + & + & - & - & - & - & - & - \\
\hline U.S.A & + & - & - & - & - & - & - & + & + & + & + & + & + \\
\hline Pakistan & - & - & - & - & - & + & - & - & - & - & - & - & - \\
\hline Iran & + & - & - & - & + & + & + & - & - & - & - & - & - \\
\hline Canada & - & + & + & + & - & + & - & - & - & - & - & - & - \\
\hline
\end{tabular}


Table3. Canada's disaster management structure at various levels

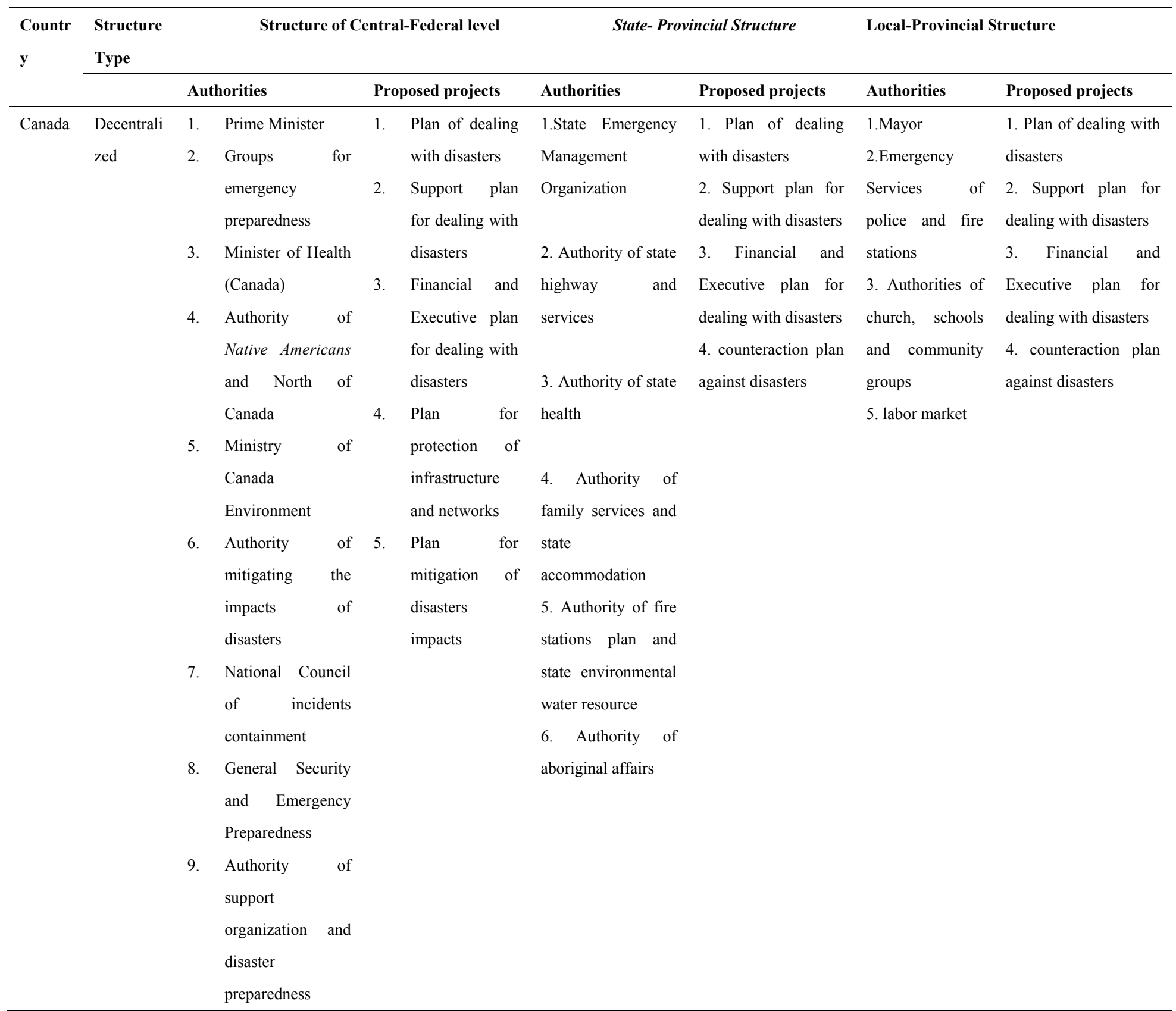


Table4. Japan's disaster management structure at various levels

\begin{tabular}{|c|c|c|c|c|c|c|c|}
\hline \multirow[t]{2}{*}{ Country } & \multirow[t]{2}{*}{$\begin{array}{l}\text { Structure } \\
\text { Type }\end{array}$} & \multicolumn{2}{|c|}{$\begin{array}{ll}\text { Structure } & \text { of } \\
\text { Central-Federal level } & \end{array}$} & \multicolumn{2}{|c|}{ State- Provincial Structure } & \multicolumn{2}{|c|}{ Local-Provincial Structure } \\
\hline & & Authorities & $\begin{array}{l}\text { Proposed } \\
\text { projects }\end{array}$ & Authorities & Proposed projects & Authorities & Proposed projects \\
\hline Japan & 7 & 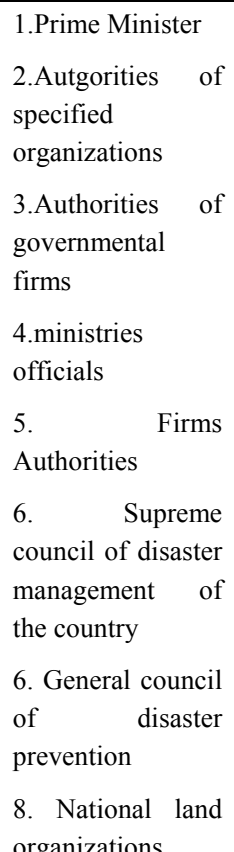 & $\begin{array}{l}\text { 1. Disaster } \\
\text { prevention plan } \\
\begin{array}{lr}2 . \quad \text { Plan } & \text { for } \\
\text { dealing } & \text { with } \\
\text { disaster } & \end{array}\end{array}$ & $\begin{array}{l}\text { 1.Governor } \\
\text { 2. Authorities of } \\
\text { administrative bodies } \\
\text { 3. local governmental } \\
\text { firms authorities } \\
\text { 4. Provincial disaster } \\
\text { management council } \\
\text { 5. Provincial } \\
\text { disasters prevention } \\
\text { council }\end{array}$ & $\begin{array}{l}\text { 1.Disaster prevention } \\
\text { plan } \\
\text { 2. Plan for dealing } \\
\text { with disaster }\end{array}$ & $\begin{array}{l}\text { 1.Governor } \\
\text { 2. Provincial disaster } \\
\text { management council } \\
\text { 3. Provincial } \\
\text { disasters prevention } \\
\text { council }\end{array}$ & $\begin{array}{l}\text { 1.Disaster prevention } \\
\text { plan } \\
\text { 2. Plan for dealing } \\
\text { with disaster }\end{array}$ \\
\hline
\end{tabular}

Table5. India's disaster management structure at various levels

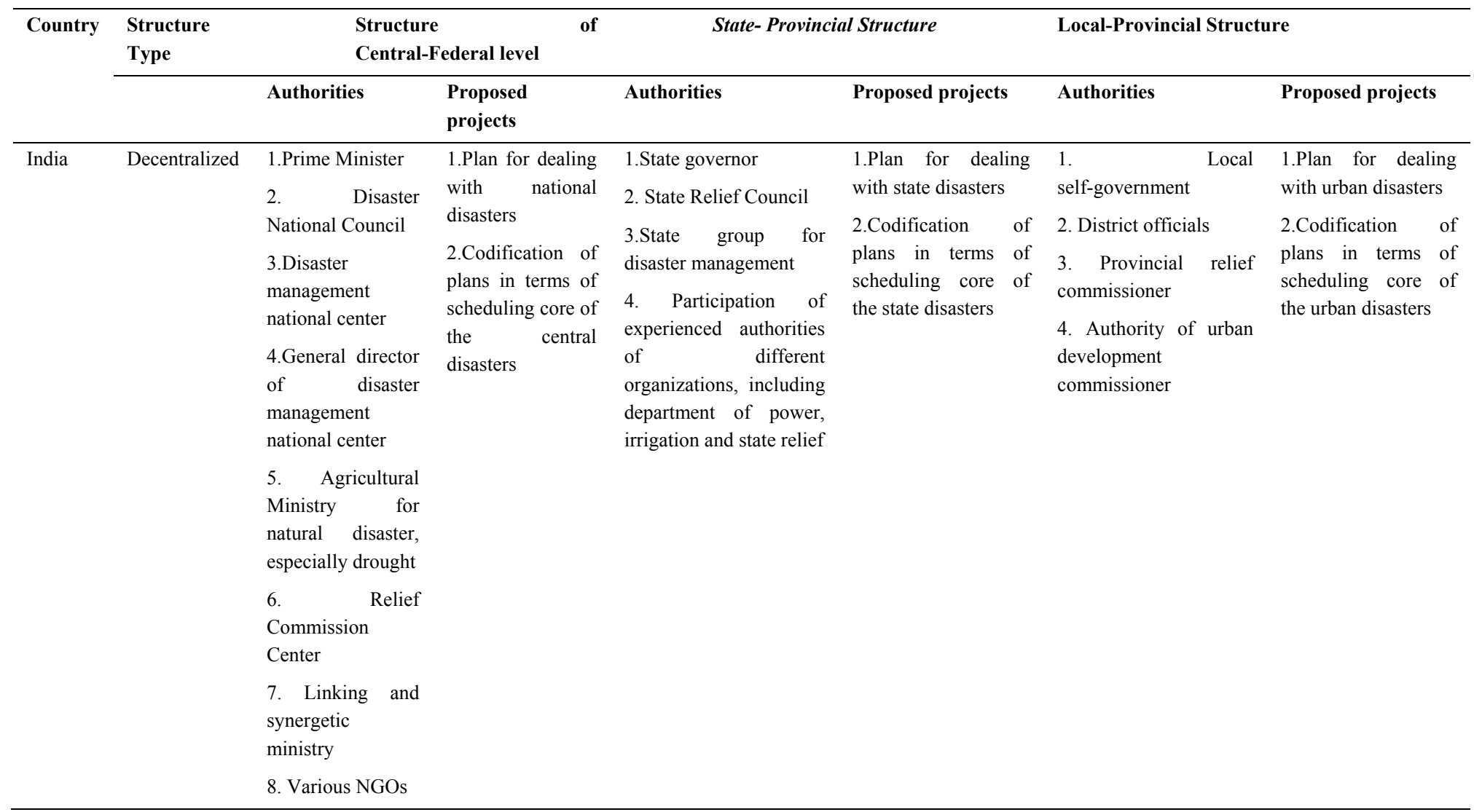


Table 6. U.S.A disaster management structure at various levels

\begin{tabular}{|c|c|c|c|c|c|c|c|}
\hline \multirow[t]{3}{*}{ Country } & \multirow[t]{3}{*}{ Structure Type } & \multirow{2}{*}{\multicolumn{2}{|c|}{$\begin{array}{l}\text { Structure } \\
\text { Central-Federal level }\end{array}$}} & \multirow{2}{*}{\multicolumn{2}{|c|}{ State- Provincial Structure }} & \multirow{2}{*}{\multicolumn{2}{|c|}{ Local-Provincial Structure }} \\
\hline & & & & & & & \\
\hline & & Authorities & $\begin{array}{l}\text { Proposed } \\
\text { projects }\end{array}$ & Authorities & Proposed projects & Authorities & Proposed projects \\
\hline \multirow[t]{23}{*}{ U.S.A } & Decentralized & 1.President of White & 1. $\underline{\mathrm{NRP}}$ & 1.State Mayor & 1. State response & 1. Local mayor & Provincial \\
\hline & & House- & 2.FRP & 2.Governor & plan & 2. Manager of local & response plan \\
\hline & & president - Red & & concerned with state & State & event recovery & Provincial \\
\hline & & Crescent- Interior & & responsible centers & confronting plans & 3.Auhthority & confronting plans \\
\hline & & Commander & & 3 State Coordinator & & operation center & \\
\hline & & headquarter- & & 4. Authority of & & 4. Local centers for & \\
\hline & & Authorities & & emergency research & & emergency crisis & \\
\hline & & FEMA and FBI- & & center & & & \\
\hline & & Interior Security & & 5. Authority of & & & \\
\hline & & Ministry- Event & & security operations & & & \\
\hline & & Recovery & & center & & & \\
\hline & & Management- & & 6. Authority of & & & \\
\hline & & Coordinator of the & & regional response & & & \\
\hline & & Federal & & coordination center & & & \\
\hline & & Government- & & 7. Authority of & & & \\
\hline & & Principle of Federal & & Regional Support & & & \\
\hline & & Stations- & & Group & & & \\
\hline & & Principle of Federal & & 8. $\underline{\text { FEMA }}$ & & & \\
\hline & & Preparedness- & & & & & \\
\hline & & Principal of Federal & & & & & \\
\hline & & Incidents & & & & & \\
\hline & & Insurance-Principla & & & & & \\
\hline & & of Federal Training & & & & & \\
\hline
\end{tabular}

In the above-mentioned table:

NRP: National Response Plan

FRP: Federal Response Plan

FEMA: Federal Emergency Management agency

JFO: Joint Field Office

JTTF: Joint Terrorism Task Force

EOC; Emergency Operation Center

HSOC: Homeland Security Operation Center

RRCC: Regional Response Center

RST: Regional Support Team

DFO: Disaster Field Office 
Table7. Turkey's disaster management structure at various levels

\begin{tabular}{|c|c|c|c|c|c|c|c|}
\hline \multirow[t]{2}{*}{ Country } & \multirow{2}{*}{$\begin{array}{l}\text { Structure } \\
\text { Type }\end{array}$} & \multicolumn{2}{|c|}{ Structure of Central-Federal level } & \multicolumn{2}{|c|}{ State-Provincial Structure } & \multicolumn{2}{|c|}{ Local-Provincial Structure } \\
\hline & & Authorities & $\begin{array}{l}\text { Proposed } \\
\text { projects }\end{array}$ & Authorities & $\begin{array}{l}\text { Proposed } \\
\text { projects }\end{array}$ & Authorities & $\begin{array}{l}\text { Proposed } \\
\text { projects }\end{array}$ \\
\hline Turkey & Decentralized & $\begin{array}{l}\text { 1.Prime Minister } \\
\text { 2.Disasters management center } \\
\text { 3. Centralized Manager of } \\
\text { disasters } \\
\text { 4. Earthquake interior council } \\
\text { 5. Centralized disasters } \\
\text { organization } \\
\text { 6. Central board of crisis } \\
\text { coordination } \\
\text { 7. Natural disasters } \\
\text { coordination board } \\
\text { 8. General director of disasters } \\
\text { 9. Disasters coordination } \\
\text { committee } \\
\text { 10. Disasters evaluation and } \\
\text { management committee } \\
\text { 11. Secretariat of disasters } \\
\text { evaluation and management } \\
\text { committee } \\
\text { 12.The ministry of labor and } \\
\text { housing- Economic Affairs- } \\
\text { National Defense - Health } \\
\text { affairs- agriculture- education- } \\
\text { Commerce and Industry- } \\
\text { Transportation and freight } \\
\text { environment- Social Security - } \\
\text { Red Crescent- General director } \\
\text { of building- General director of } \\
\text { Executive and Research Affairs } \\
\text { - the general director of civil } \\
\text { defense. General director of } \\
\text { hydraulic affairs of Province }\end{array}$ & $\begin{array}{l}\text { Various } \\
\text { kinds of } \\
\text { confronting } \\
\text { and response } \\
\text { plan }\end{array}$ & $\begin{array}{l}\text { 1.Governor(Province } \\
\text { Mayor) } \\
\text { 2. Country } \\
\text { administrative boards } \\
\text { 3. Provincial } \\
\text { Gendarmerie } \\
\text { 4. Provincial army } \\
\text { commander } \\
\text { 5. Provincial police } \\
\text { chief } \\
\text { 6.Provincial social } \\
\text { defense director } \\
\text { 7. Director of } \\
\text { provincial education } \\
8 . \quad \text { Director of } \\
\text { provincial labor and } \\
\text { housing } \\
9 . \quad \text { Director of } \\
\text { provincial agriculture }\end{array}$ & $\begin{array}{l}\text { Various } \\
\text { kinds of } \\
\text { confronting } \\
\text { and response } \\
\text { plan }\end{array}$ & $\begin{array}{l}\text { 1.City governor } \\
\text { 2.Adminstrative } \\
\text { board of city } \\
\text { 3.Relief } \\
\text { committee of } \\
\text { cities }\end{array}$ & $\begin{array}{l}\text { Various } \\
\text { kinds of } \\
\text { confronting } \\
\text { and response } \\
\text { plan }\end{array}$ \\
\hline
\end{tabular}


Table 8. Iran's disaster management structure at various levels

\begin{tabular}{|c|c|c|c|c|c|c|c|}
\hline \multirow[t]{2}{*}{ Country } & \multirow[t]{2}{*}{ Structure Type } & \multicolumn{2}{|c|}{ Structure of Central-Federal level } & \multicolumn{2}{|c|}{ State-Provincial Structure } & \multicolumn{2}{|c|}{ Local-Provincial Structure } \\
\hline & & Authorities & $\begin{array}{l}\text { Proposed } \\
\text { projects }\end{array}$ & Authorities & Proposed projects & Authorities & $\begin{array}{l}\text { Proposed } \\
\text { projects }\end{array}$ \\
\hline \multirow[t]{22}{*}{ Iran } & Semi-centralized & 1.President & Country & 1.Governor & 1.Mayor & The Organizations & \\
\hline & & 2.Interior Minister & Comprehensive & 2.Provincial & 2.Mayor of district & and & \\
\hline & & 3.First & rescue Plan & subcommittee & & Headquarters for & \\
\hline & & President & 2. Law of welfare & for mitigation of & & crisis prevention and & \\
\hline & & 4. Chairman of & system structure & natural & & management & \\
\hline & & Red Crescent & and social security & disasters & & & \\
\hline & & 5. Minister of & 3.Sataff for crisis & impacts & & & \\
\hline & & Cooperatives, & prevention and & & & & \\
\hline & & Labor and Social & management & & & & \\
\hline & & Welfare & during occurrence & & & & \\
\hline & & 6. Commander of & of unexpected & & & & \\
\hline & & Sipah Pasdaran & events & & & & \\
\hline & & 7. Unexpected & & & & & \\
\hline & & events Staff & & & & & \\
\hline & & 8.National & & & & & \\
\hline & & committee & & & & & \\
\hline & & mitigation & & & & & \\
\hline & & natural disasters & & & & & \\
\hline & & impacts & & & & & \\
\hline & & 9.Ministry & & & & & \\
\hline & & Roads \& Urban & & & & & \\
\hline & & Development & & & & & \\
\hline
\end{tabular}

\section{Results and Discussion}

1) The structure of countries decentralized structure, which is different from Iran structure, as the structure of Iran is semi-centralized.

2) With regard to the afore-mentioned considerations, it can be claimed that there can be a direct relation between development and effective factors on promotion of quantitative and qualitative levels, moreover, the government structure may play a role in the mentioned relation.

3) As the four disasters are mutual among Iran and U.S.A, Turkey, India, japan, Canada, it can be deduced that authorities should take these countries experience into account for revising the disaster management structure and planning.

4) With regard to the tables, and findings which imply the existence of direction relation between decentralized structure and optimal disaster management, it can be construed that the countries with decentralized structure are more successful in confronting natural disasters, compared to the countries with centralized structure of disasters management. In addition, it is essential to obey the three principles (accuracy, speed and precision) in all phases of disaster management, since of a specific governmental structure of Iran, during the response to the disasters. Meanwhile, the afore-mentioned subjects should be considers at all levels till the last social level.

\section{Suggestions}

We should point out that there exist legal vacuums and objections in national and macro legal documents, 
especially in the case of Iran's disaster management and there is an overlap between a lot of activities and absence of balanced attention to disaster management fields, on contrary to the developed countries. For instance, in the case of Varzaqan earthquake (Located in east Azerbaijan, Iran), according to the law of establishing the national disaster management (approved in 2008), all organizations and institutions (both public and private sectors), military organizations, municipality and other bodies depended on them and private sector firm and cooperatives are obliged to take an action during disasters confrontation.

1) The existence of execution issues and inconsistencies of the organizations and other institutions that are involved in the execution phase should be regarded as the slippage for disaster management in Iran. While, the findings indicate that the disaster management of the selected countries is not suffering from such problems and the task of each unit is explicitly specified till the last environmental level.

2) The author has also observed excessive attention to relief and rescue activities and disaster management cycle and ignorance other fields of disaster management cycle, while in the developed countries; there exists a balanced attention toward their disaster management system.

3) Author has also identified the absence of a private institution for dealing with all phases of disaster management process, while in the developed countries all organizations and institutions all are cognizant of technical knowledge about disaster management, which encompasses all aspect of the disaster management, in a balanced manner.

4) The author has also found out that there are some organizations in Iran like Earthquake Research Institute and Institute of Seismology, which merely deal with earthquake disaster, and their capacity and potentials for dealing with other events are being wasted. Our findings showed that, in Iran no heed is paid to the disaster in advance (prior to its occurrence), while the developed countries are focused on the prior condition of disasters. So, the disaster consequences and negative impacts are higher than that of developed countries. In the Iranian disaster management system, this fact has been neglected. But, the present studies have highlighted the positive effect of paying attention to disasters, before their occurrence.

5) To wrap it up, the findings proved the absence of unite attitude toward the crisis concept in management system of Iran. Regardless of negative meaning of crisis and disaster, the broadness of the crisis management concepts should be consider as one of the main problem in this context. That is, each legislative and executive body has its own perception of the concept. It means that, as long as the absence of obvious understanding of the problem, we will encounter with different attitudes toward the crisis management and inability in codifying a precise strategy for disaster confrontation.

6) Author has also noticed a weakness of authorities in documentation phase within disaster management system, compared to the developed countries. Therefore, we can easily notice the absence of technical observation of the damaged and ruined structures and the act of documenting after the occurrence of disasters. In other words, there is a lack of learning and using the previous experiences in Iranian disaster management system, which should be overcame in order for precautionary planning

\section{References}

Altntas, K. H., \& Delooz, H. (2004). The problems faced by three government disaster response teams of Ankara City during the Marmara earthquake-1999 response. European Journal of Emergency Medicine, 11(2), 95-101. http://dx.doi.org/10.1097/00063110-200404000-00008

Asadi F. A, M. M. (2004). Final Report on documentation of comprehensive relief and rescue plan. Red Crescent Society of Islamic Republic of Iran, Vol.3, Tehran.

Corbacioglu, S. (2004). Intergovernmental collective action in complex environments: Towards a self-adaptive Turkish disaster management system.

Denis, H. (2001). Managing disasters involving hazardous substances in Canada: technical and sociopolitical issues. Journal of hazardous materials, 88(2), 195-211. http://dx.doi.org/10.1016/S0304-3894(01)00267-9

Dorisf et al. (2004). Emergency Preparedness on Community's Response. Family Community Health, 27(3), 266-272. http://dx.doi.org/10.1097/00003727-200407000-00014

Evans, N. (1995). Earthquake Disaster Preparedness in Japan, and Its Effect on the Outcome of the Great Hanshin Earthquake (Doctoral dissertation, University of Sheffield, School of East Asian Studies).

Gow, G. A. (2003). Canadian telecommunications policy and the national disaster mitigation strategy: Observing wireless enhanced 9-1-1 (Doctoral dissertation, SIMON FRASER UNIVERSITY). 
Groat, L. N., \& Wang, D. (2005). Architectural Research Methods (Translated by Ali Rezaeifar), Tehran University Publication, Tehran.

Iranian Red Crescent Society. (2003). Comprehensive relief and rescue plan. Tehran.

Jafari, A. (2005). Novel Geographical of the Countries. Hamun press, Tehran.

Rezaei, B. (2011). Crisis Management, Yadavaran International Research and Publications Company.

Shadab, F. (2005). The United States of America. Hamun press, Tehran.

Tabarsa, G. (2002). Investigation and Interpretation of Relief and Rescue Index. Research Plan, No. 2. Tehran.

Tayebi, S. J. (2009). Comparative Study on Disasters Management in Selected Countries. Academy of Medical Sciences.

Wachtendorf, T. (2000). Interaction between Canadian and American governmental and non-governmental organizations during the red river flood of 1997.

Weiss, T. G. (2005). Military-civilian interactions: humanitarian crises and the responsibility to protect. Rowman \& Littlefield.

World Health Organization. (1997). Guide to Sanitation in Natural Disasters. Translated by Yusefi, Hodi, Guya and Jamali, Tehran.

\section{Copyrights}

Copyright for this article is retained by the author(s), with first publication rights granted to the journal.

This is an open-access article distributed under the terms and conditions of the Creative Commons Attribution license (http://creativecommons.org/licenses/by/4.0/). 